\title{
Carbon Dioxide Emission, Human Capital and Economic Growth: Long-Run Relation with Short-Run Dynamics
}

\author{
Melaku Adinew Ayitehgiza \\ Collage of Business and Economics; Dire Dawa University, PO box 1362, Dire Dawa, Ethiopia
}

\begin{abstract}
This paper examine the causal relationship between $\mathrm{CO}_{2}$ emission, human capital, and economic growth using an autoregressive distributed lag model during a period of 1981-2017. The result showed that $\mathrm{CO}_{2}$ emission has a negative effect in the long-run and positive effect in the short-run, while human capital has a positive effect in the long-run and negative effect in the short-run on economic growth in Ethiopia. The result of Granger causality showed that a bidirectional causal relationship from reduction of $\mathrm{CO} 2$ emission to economic growth, from human capital to economic growth and a unidirectional causal relationship between human capital and reduction of $\mathrm{CO} 2$ emission in Ethiopia. However, there is no significant causality from human capital to reduction of $\mathrm{CO} 2$ emission. Policymakers should emphasize human capital development and establish policies, strategies, and programs related to the reduction of $\mathrm{CO} 2$ emission in Ethiopia.
\end{abstract}

Keywords: $\mathrm{CO}_{2}$ emission, Human Capital, Economic Growth, ARDL Model, Ethiopia

DOI: $10.7176 / \mathrm{JETP} / 10-5-01$

Publication date:September $30^{\text {th }} 2020$

\section{Introduction}

In recent research, the relationship between economic growth and climate change is an important issue. Climate change is an obstacle to economic growth (Mc Sweeney et al., 2010; Abidoye \& Odusola, 2015; Robinson et al., 2013; Stern, 2008). The world economy is facing serious challenges with global climate change. To address this problem, there is international pressure to reduce carbon emissions for all countries. Change in the trend among economic activities, taking into account the environmental values (Costantini \& Monni, 2008; Muttarak \& Lutz, 2014; Striessnig, Lutz, \& Patt, 2013). A change in the production system with technological changes helps to save energy and reduce emissions.

Carbon dioxide (CO2) emission is the major source of global climate change (IPCC, 2013; World Bank, 2010). Global warming; rainfall fluctuations: disease; decreased agricultural production; melt of ice; countries flooded; increased locusts reproduction; animal death, and migration are major indicators of climate change. The loss of biodiversity, destruction of forests, air and water pollution, chemical and energy production risks are some challenges of the environment.

Climate change is the result of pollutants released into the atmosphere by human activity (World Bank, 2010; UN, 1992). Human- made activities have been to increase the concentration of $\mathrm{CO}_{2}$ in the atmosphere. The concentration of $\mathrm{CO}_{2}$ emission levels increasing in the atmosphere leads to increases global temperature more than two degrees (IPCC, 2013). The costs of climate change avoiding that to reduce about $1 \%-3.5 \%$ from the gain of global gross domestic product in 2050 (Stern, 2008).

Education is very important factor for people to understand about climate change and its impact on the environment and can reduce vulnerability to climate change (UNESCO, 2011). Human capital is an important issue that directly affects the economic growth or indirectly the generation of innovation and technology (Claude and Ralph, 2016). Economic growth depends on human capital (World Bank, 2018). The low levels of human capital development have negative consequences on economic activities.

Human capital and its linkage with $\mathrm{CO}_{2}$ emissions are essential element for climate change. Human capital development is an important factors that to improve the production process (Becker, 1975; Smith, 1904; UN, 1990) and more efficient of utilization of resources and helps to produce more output using less energy and materials, which has completely reduced the problem of over exploitation of natural resources and the environment degradation (Dinda, 2009).

Ethiopia has experienced a fastest economy growth dependent mainly on agriculture but historically the country has been affected by weather extremes and vulnerable to the effects of climate change. In fact that, it does not have passable monitoring systems for the forecast of extreme events or the assessment of possible changes in weather patterns; as a result, the situations of human capital development still remain challenging (World Bank, 2018; UN, 2018). The status for the human development index is very low (UN, 2019).

As human capital development improves, economic growth can reduce carbon emissions in developing countries like Ethiopia. There are several studies observed that the causal linkage between carbon dioxide emission and economic growth (Abidoye \& Odusola, 2015; Andersson \& Karpestam, 2013; Aye \& Edoja, 2017; Nuryartono \& Rifai, 2017; Nyasha, Gwenhure, \& Odhiambo, 2018; Robinson, Strzepek, \& Cervigni, 2013; Alam, 2014; Azomahou et al., 2005; Jardón et al., 2017; Kasperowicz, 2015; Mikayilov et al., 2018; Ru et al., 2018; Saidi \& 
Hammami, 2015; Wang et al., 2017) and human capital with $\mathrm{CO}_{2}$ emission (Bashir et al., 2019; Bano et al., 2018; Bashir \& Susetyo, 2018; Li \& Ouyang, 2019).

However, some empirical literatures in Ethiopia have examined the potential impacts of climate change on economic growth and human capital on economic growth. This show, there is not much attention and have not been able to identified the interrelationships between human capital development and carbon dioxide emission. Now there are questions about the relationship between human capital development and $\mathrm{CO}_{2}$ emissions or the relationship between $\mathrm{CO}_{2}$ emissions and economic growth. Thus, Can human capital effect for the reduction of $\mathrm{CO} 2$ emissions in terms of economic growth? Therefore, a study is needed to determine the link between human capitals; carbon emissions and economic growth in Ethiopia.

The paper is organized as follows: Section 2 theoretical background on human capital and carbon dioxide emission focusing on economic growth. Section 3 describes the data and the empirical methodology. Section 4 analyses the results, and Section 5 concludes.

\section{Theoretical background of production function, human capital and pollution}

The main purpose of this study is to examine the relationship between human capital, carbon dioxide emission and economic growth. Following Perman et al, (2003) considering a good economy, the production output is produced by of factor inputs such as labor, capital, raw materials or land. The production function of this economy can be expressed as follow:

$Y_{t}=f\left(M_{t} A_{t} L_{t}\right)$

Where $Y_{t}$ is aggregate output in $t, L_{t}$ is labor force in time $t, A_{t}$ is technology in time $t$ and $M_{t}$ is a by-product (pollution) during production process when using of raw materials (natural resource) from the environment in time t. Pollution is inevitable and is related to production process. Pollution per unit output may be increasing or decreasing depending on the improvement of the production technology in economic activities. The empirically form of the model can be written as:

$G D P=\beta_{0}+\beta_{1} H C_{t}+\beta_{2} C O_{2 t}+\varepsilon_{t}$

Where GDP is the economic growth, $\mathrm{HC}$ is human capital and $\mathrm{CO} 2$ emission can be captured as pollution of a by-product. The parameters $\beta 0, \beta 1$, and $\beta 2$ are the output elasticity's with respect to human capital and $\mathrm{CO} 2$ respectively; $\mathrm{t}$ is the time trend and $\varepsilon$ is the error term.

\section{Methodology}

The time-series data of the gross domestic product (GDP) (current U.S. Dollars), human capital (HC) is proxy on years of schooling and returns to education and $\mathrm{CO}_{2}$ is proxy for carbon dioxide damage (current U.S. Dollars) which cover the period from 1981 to 2017 , based the data availability. The data has been obtained from the World Development Indicators of the World Bank.

In order to investigate whether data are stationary or not and using appropriate econometric techniques for analysis of the data. Here, to determine the stationary property of the data to be apply the Augmented DickeyFuller (ADF) (Dickey \& Fuller, 1979) and the Phillips-Peter (PP) (Phillips and Perron, 1988) tests.

The Autoregressive Distributed Lag (ARDL) bounds testing approach used to confirm long-run and shortrun relationships between economic growth, human capital and $\mathrm{CO} 2$ emissions, which was established by (Pesaran and Shin, 1999) and (Pesaran, Shin, and Smith, 2001). The ARDL approach has more benefits compared to other existing co-integration methods; First, It does not require all variables in the study to be integrated in the same order. Second, the model estimation is more effective when the sample size is small. Third, the long-term of the model obtains an unbalanced estimate (Marques, Fuinhas and Menegaki, 2016). The mathematical representation of ARDL used in this study is as follows:

$\Delta \ln G D P_{t}=\varphi 0+\beta_{1} \ln G D P_{t-1}+\beta_{2} \ln H C_{t-1}+\beta_{3} \ln C O_{2 t-1}+\sum_{i=1}^{p} \delta_{1} \Delta \ln G D P_{t-i}+\sum_{i=1}^{p} \delta_{2} \Delta \ln H C_{t-i}+$ $\sum_{i=1}^{p} \delta_{3} \ln C O_{2 t-i}+\varepsilon_{t}$

Where all variables are mentioned earlier, $\varphi_{0}$ is the deterministic drift parameter, $\Delta$ denotes changes to existing variables, and $\mathrm{P}$ is the optimum lags lengths. The Wald test of $\mathrm{F}$ test is using to test the significance of the lagged levels of variables to determine the presences of the co-integration relationship between variables in the above equation 3. The test of null hypothesis $\mathrm{H}_{0}: \delta_{1}=\delta_{2}=\delta_{3}=0$, meaning that, null hypothesis cannot reject for the absence of co-integration of the variables, on the other hand, alternative $\mathrm{H}_{1}, \delta_{1} \neq \delta_{2} \neq \delta_{3} \neq 0$ which implies that the hypothesis of the existence of such a relationship can be rejected.

The ARDL bounds testing approach for co-integration analysis has two steps. The first step, to determine the existence of a long run co-integrating relationship among the variables by using the F-statistics or Wald-coefficient test by comparing the critical values proposed by Pesaran, Shin, and Smith, (2001). According to Pesaran, Shin, and Smith, (2001), there are two critical values, such as lower and upper bound critical for a given level of significance. The $\mathrm{I}(0)$ critical values referred to as lower-bound while the I (1) critical values referred to as upperbound critical values. If the calculated F-Statistic is higher than the upper bounds, the null hypothesis of no cointegration is rejected, which is indicating, the existence of a long-run co-integration relationship between the 
variables. If the calculated F-statistic is below the lower bound, the null hypothesis of no co-integration is cannot be rejected, meaning that, the absence of a long-run equilibrium relationship. In the Second step, estimating the coefficient of long-run and short-run and the coefficient of error-correction model (ECM). The error correction model based on the ARDL approach is established as follows.

$\Delta \ln G D P_{t}=\gamma_{0}+\sum_{i=1}^{p} \gamma_{1} \Delta \ln G D P_{t-i}+\sum_{i=1}^{p} \gamma_{2} \Delta \ln H C_{t-i}+\sum_{i=1}^{p} \gamma_{3} \ln C O_{2 t-i}+\gamma_{4} E C M_{t-1}+\varepsilon_{t}$

Where ECM (-1) is the speed of adjustment of parameter which is must be negative and significant.

\section{Results and discussion}

This part is to examine the causal relationship between carbon dioxide emission, human capital, and economic growth in Ethiopia. To this effect, the time series data property was examined. The dynamic relationship was done using the ARDL model after conducting a pre-estimation test.

\subsection{Unit root test}

The stationary tests examine the stationary property of variables for the order of integration of each series of data. With this regard, to determine stationarity property of the variables used namely Augmented Dickey-Fuller (ADF) test and the Phillips Perron (PP) test (Table 1).

Tables 1:- Report the results of the Augmented Dickey-Fuller and Phillips-Perron unit root tests.

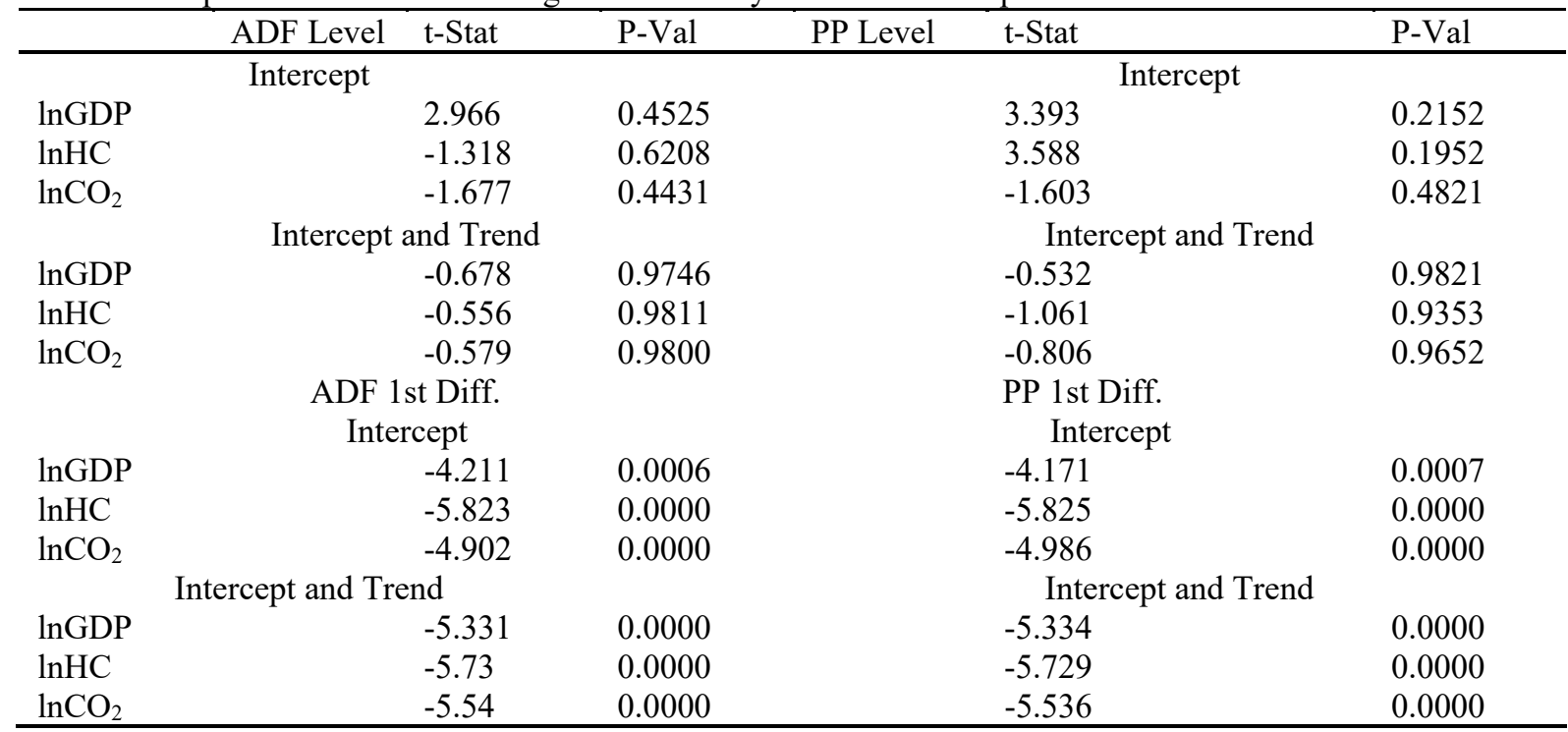

$\mathrm{ADF}$ and PP tests with only intercept and intercept and trend at $1 \%$ level of significance

The ARDL bounds test is considering assumption of variables integrated at I (0) or I (1) (Pesaran, Shin, and Smith, (2001). Thus, the result of the ADF and the PP test of unit root test of the variables were non-stationarity at level and stationary at the first difference and reject of null hypothesis for the variables captured in this study. Therefore, all the variables were integrated at order one.

\subsection{ARDL bounds tests}

The existence of the long-run and short run relationships among the variables of interest was determined using ARDL bounds test (Table 2).

Table 2: ARDL Bounds Test

\begin{tabular}{lll}
\hline Test Statistic & Value & $\mathrm{K}$ \\
\hline F-statistic & 10.017 & 2 \\
Critical Value Bounds & & \\
Significance & I0 Bound & I1 Bound \\
$10 \%$ & 3.17 & 4.14 \\
$5 \%$ & 3.79 & 4.85 \\
$2.5 \%$ & 4.41 & 5.52 \\
$1 \%$ & 5.15 & 6.36 \\
\hline
\end{tabular}

The F-statistic tests the null hypothesis of no co-integration

As seen in Table 2 the above, the joint significance of the variables using the ADRL bound test indicates the presence of long-run relationship (co-integration) at 1 percent level of significance. The calculated F-statistic (10.017) is more than the upper-bound of 1 percent critical value (6.36). Therefore, there is a long-run relationship between the variables. Once the variables have confirmed co-integration, the next step is to estimate the error 
correction model to identify short-run and long-run results about economic growth in Ethiopia. The long-run and short-run results of the ARDL model were reported on Table 3.

Table 3: Results using ARDL Approach (Long-run and Short-run)

\begin{tabular}{|c|c|c|c|c|}
\hline & Short -Run & \multicolumn{3}{|c|}{ Depend variable: $\ln G D P_{t}$} \\
\hline Variables & Coefficients & Std. Error & $\mathrm{t}$-Statistic & Probability \\
\hline $\ln \mathrm{HC}$ & -0.2428416 & 5.220217 & -0.05 & 0.963 \\
\hline $\operatorname{lnCO} 2$ & 0.1539437 & 0.0817898 & 1.88 & $0.071 *$ \\
\hline $\operatorname{ECT}(-1)$ & -0.907735 & 0.1740135 & -5.22 & $0.0000 * *$ \\
\hline & Long-Run & \multicolumn{3}{|c|}{ Depend variable: $\ln G D P_{t}$} \\
\hline Variables & Coefficients & Std. Error & $\mathrm{t}$-Statistic & Probability \\
\hline $\ln \mathrm{HC}$ & 5.912268 & 0.7086919 & 8.34 & $0.0000 * *$ \\
\hline $\operatorname{lnCO} 2$ & -0.2071585 & 0.0462585 & -4.48 & $0.0000 * *$ \\
\hline
\end{tabular}

$*, * *$ Indicate statistical significance at $10 \%$ and $1 \%$ levels, respectively:

The results of the long-term ARDL model showed that the coefficient of human capital has a positive and statistically significant effect on economic growth at $1 \%$ level of significant. This implies that human capital will increase at a rate of 1 per cent while economy growth increases by $5.912 \%$. This result indicates that human capital, like the developing country (Ethiopia), has a major role in the development and adoption of new technology. This finding has been proven to be consistent with previous studies (Claude Diebolt and Ralph Hipple, 2016; Costantini \& Monni, 2008; Curea \& Ciora, 2013; Dinkneh \& Jiang, 2015; Mehrara \& Musai, 2013; Mitaj, Muco, \& Avdulaj, 2016; Obialor, 2017; Salisu \& Bubari, 2019).

Furthermore, the coefficient of carbon dioxide emission is negative and statistically significant at $1 \%$ in the long run. This indicates that carbon dioxide emission increase by $1 \%$ while economic growth decreases by $0.21 \%$. The finding is consistent with previous studies conducted by (Dell,.Jones and Olken, 2008; Conway and Schipper, 2011; Robinson, Strzepek and Cervigni, 2013; Abidoye and Odusola, 2015; Samuel and Nicholas, 2016; Roos, 2017; Kahn et al., 2019; Asongu and Odhiambo, 2020)

As shown the short-run dynamics relationship between carbon dioxide emission, human capitals and economic growth. Carbon dioxide emission has a significant effect on economic growth in the short-run. But human capital has insignificant or less impact on economic growth in Ethiopia in the short term. Because, the status of human development index of the county is very low. Which means 50.9 percent of its population are illiterate (UN, 2019). The rural populations of the country still a serious challenge to access the education system.

According to the results in table 3, the coefficient of the error correction term must be a negative sign and statistically significant. Therefore, the coefficient of the error correction term is negative and statistically significant at 1 percent. This represents a 91.8 percent of the disequilibrium of the preceding year's shock adjusting back to the long-run equilibrium in the present year.

\subsection{Granger causality}

The study applied the Granger-causality test to indicate the direction of causality between human capital, climate change (CO2), and economic growth. The results of Granger causality tests were reported in Table 4. The null hypothesis of the $\ln \mathrm{HC}$ does not Granger Cause lnGDP; $\operatorname{lnCO} 2$ does not Granger Cause lnGDP; lnGDP does not Granger Cause lnHC; lnGDP does not Granger Cause $\operatorname{lnCO} 2$ and $\operatorname{lnCO} 2$ does not Granger Cause $\ln \mathrm{HC}$ was rejected at the $5 \%$ significance level. The result was shown carbon dioxide emissions cause economic growth and the opposite is true. Also human capital cause economic growth and the opposite are true. This means, there is a bidirectional causality of human capital and carbon dioxide emissions with economic growth. On the other hand, carbon dioxide emission causes human capital. However, the opposite is invalid. Meaning that, there is a unidirectional causality relation between carbon dioxide and human capital. The short-run estimation of the result, human capital contribution is very low for the rising of carbon dioxide emissions. This finding has been proven to be consistent with previous studies (Bano et al., 2018).

Table 4: Granger-causality Tests

\begin{tabular}{lll}
\hline Null Hypothesis: & F-Statistic & Probability \\
\hline lnHC does not Granger Cause lnGDP & 22.099 & $0.0008^{* *}$ \\
lnCO2 does not Granger Cause lnGDP & 22.453 & $0.0007^{* *}$ \\
lnGDP does not Granger Cause lnHC & 6.2585 & $0.021^{*}$ \\
lnCO2 does not Granger Cause lnHC & 5.4806 & $0.0288^{*}$ \\
lnHC does not Granger Cause lnCO2 & 3.5663 & 0.0735 \\
lnGDP does not Granger Cause lnCO2 & 13.15 & $0.0032^{* *}$ \\
\hline
\end{tabular}

** and * rejection of the null hypothesis at $1 \%$ and $5 \%$ significance level respectively

\subsection{Diagnostic and stability tests}

The diagnostic tests employed to confirm the ARDL model fitness of test for heteroskedasticity; serial correlation; 
normality and model specification were reported in Table 5. The problem of heteroskedasticity was tested by Breusch-Pagan-Godfrey test and the null hypothesis of the heteroskedasticity test cannot reject at the 5\% level of significance. This means, there is no heteroskedasticity problem in the residuals. The serial correlation was tested by Breusch-Godfrey serial correlation LM test and null hypothesis of serial correlation cannot reject at the 5\% level of significance. The result showed that no serial correlation. The functional misspecification was tested by the Ramsey RESET test and the null hypothesis of functional form cannot be rejected at the 5\% significance level. This means, it is the specification form. The normality test by Jarque-Bera test and the null hypothesis of no normality distribution is cannot reject at 5\% level of significant. The result show the residual is normality distributed.

Table 5: ARDL Model Diagnostic Tests

\begin{tabular}{ll}
\hline Bounds testing to co-integration & Probability \\
\hline Heteroskedasticity Test: Breusch-Pagan-Godfrey & 0.3031 \\
Breusch-Godfrey Serial Correlation LM Test & 0.6658 \\
Jarque-Bera Test normality test & 0.25939 \\
Ramsey RESET Test & 0.5477 \\
Durbin-Watson d-statistic & 1.854894 \\
\hline
\end{tabular}

Statistical significance at $5 \%$ levels, respectively

In order to identify the structural stability of short-run and long-run coefficients in the ARDL model to applied the CUSUM and CUSUM of Squares residual tests. Fig. 1 and 2 show the CUSUM and CUSUM of Squares residual tests of the ARDL model lie within the 5\% significance level. This means, both long-run and short-run coefficients were verify and validate the ARDL integration test.
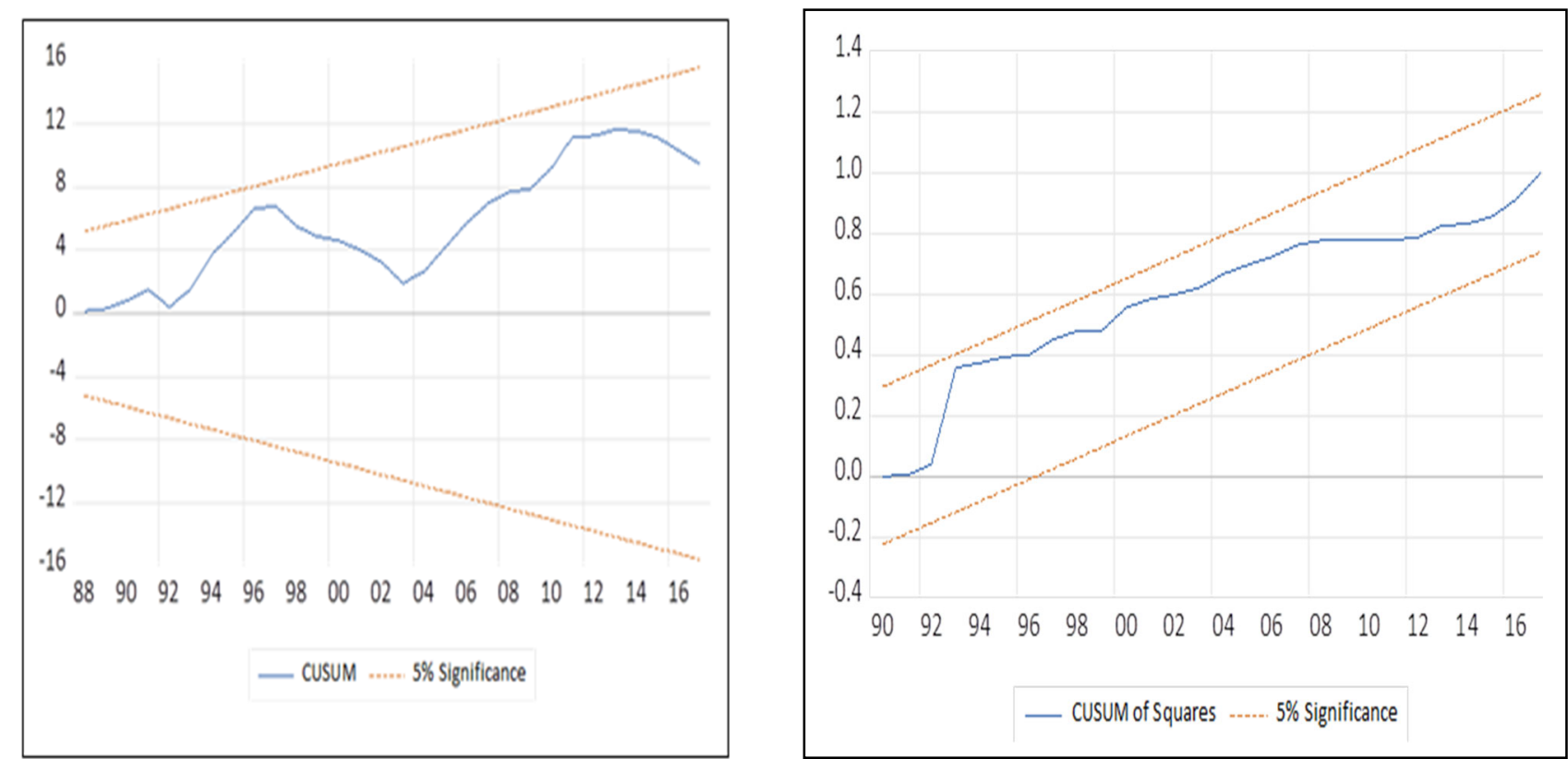

Figure 1: Parameter stability CUSUM test

Figure 2: Parameter stability CUSUM of Squares test

\section{Conclusion}

This study examined the causal relationship between $\mathrm{CO}_{2}$ emission, human capital, and economic growth in Ethiopia. The study used autoregressive distributed lag bounds estimation technique and data were covered from the period of 1981-2017. The ARDL model used to investigate the existence of a long-run and short-run relationship among the variables; and the Granger causality within VAR to test the direction of causality between the variables.

Results indicate that carbon dioxide emissions variables have a negative impact and human capital positive impact on economic growth in the long-run and co-integration in the model economic growth as a dependent variable. The results of Granger causality from economic growth to carbon dioxide emissions or from carbon dioxide emissions to economic growth and from economic growth to human capital or from human capital to economic growth is a bidirectional causal relationship from reduction of $\mathrm{CO} 2$ emission to economic growth, from human capital to economic growth and a unidirectional causal relationship between human capital and reduction of $\mathrm{CO} 2$ emission. However, there is no significant Granger causality human capital to carbon dioxide emissions in the short run. 


\section{Reference}

Abidoye, B. O., \& Odusola, A. F. (2015). Climate Change and Economic Growth in Africa: An Econometric Analysis. (January), 277-301. https://doi.org/10.1093/jae/eju033

Alam, J. (2014). On the Relationship between Economic Growth and CO2 Emissions : The On the Relationship between Economic Growth and $\mathrm{CO} 2$ Emissions : The Bangladesh Experience. IOSR Journal of Economics and Finance (IOSR-JEF) e-ISSN: 2321-5933, p-ISSN: $2321-5925 ., \quad 5(6), \quad 36-41$. https://doi.org/10.9790/5933-05613641

Andersson, F. N. G., \& Karpestam, P. (2013). CO2 emissions and economic activity: Short- and long-run economic determinants of scale, energy intensity and carbon intensity. Energy Policy, 61, 1285-1294. https://doi.org/10.1016/j.enpol.2013.06.004

Asongu, S. A., \& Odhiambo, N. M. (2020). Governance , CO 2 emissions and inclusive human development in sub-Saharan Africa. Energy Exploration \& Exploitation, 38(1), $18-36$. https://doi.org/10.1177/0144598719835594

Aye, G. C., \& Edoja, P. E. (2017). Effect of economic growth on CO 2 emission in developing countries : Evidence from a dynamic panel threshold model Effect of economic growth on $\mathrm{CO} 2$ emission in developing countries : Evidence from a dynamic panel threshold model. Cogent Economics \& Finance, 90(1). https://doi.org/10.1080/23322039.2017.1379239

Azomahou, T., Laisney, F., Azomahou, T., \& Laisney, F. (2005). Economic Development and CO 2 Emissions : A Nonparametric Panel Approach Economic Development and CO 2 Emissions: A Nonparametric Panel Approach. Discussion Paper No. 05-56 Economic, ftp://ftp.zew.de/pub/zew-docs/dp/dp0556.pdf.

Bano, S., Zhao, Y., Ahmad, A., Wang, S., \& Liu, Y. (2018). Identifying the impacts of human capital on carbon emissions in Pakistan. Journal of Cleaner Production. https://doi.org/10.1016/j.jclepro.2018.02.008

Bashir, A., Husni Thamrin, K. M., Farhan, M., Mukhlis, \& Atiyatna, D. P. (2019). The causality between human capital, energy consumption, CO 2 emissions, and economic growth: Empirical evidence from Indonesia. International Journal of Energy Economics and Policy, 9(2), 98-104. https://doi.org/10.32479/ijeep.7377

Bashir, A., \& Susetyo, D. (2018). the Relationship Between Economic Growth, Human Capital, and Agriculture Sector: Empirical Evidence From Indonesia. International Journal of Food and Agricultural Economics (IJFAEC), 6(4), 35-52.

Becker, G. S. (1975). A Theoretical and Empirical Analysis with Special Reference to Education (3rd Edition).

Claude Diebolt and Ralph Hipple. (2016). The long-run impact of human capital on innovation and economic development in the regions of Europe. Applied Economics, (7), 51:5, 542-563.

Conway, D., \& Schipper, E. L. F. (2011). Adaptation to climate change in Africa: Challenges and opportunities identified from Ethiopia. Global Environmental Change, 21(1), 227-237. https://doi.org/10.1016/j.gloenvcha.2010.07.013

Costantini, V., \& Monni, S. (2008). Environment, human development and economic growth. Ecological Economics, 64(4), 867-880. https://doi.org/10.1016/j.ecolecon.2007.05.011

Curea, Ş. C., \& Ciora, C. (2013). The impact of human capital on economic growth. Quality - Access to Success, 14(SUPPL. 1), 395-399. https://doi.org/10.1016/s2212-5671(15)00258-0

Dickey, D. A., \& Fuller, W. A. (1979). Distribution of the Estimators for Autoregressive Time Series With a Unit Root. 74(366), 427-431.

Dinda, S. (2009). Climate change and human insecurity. International Journal of Global Environmental Issues, 9(1-2), 103-109. https://doi.org/10.1504/ijgenvi.2009.022088

Dinkneh, G. B., \& Jiang, Y. (2015). The Impact of Human Capital on Economic Growth in Ethiopia. Journal of Economics and Sustainable Development, 6(16), 109-119.

IPCC. (2013). CLIMATE CHANGE 2013: The Physical Science Basis. Contribution of Working Group I to the Fifth Assessment Report of the Intergovernmental Panel on Climate Change [Stocker, T.F., D. Qin, G.-K. Plattner, M. Tignor, S.K. Allen, J. Boschung, A. Nauels, Y. Xia,.

Jardón, A., Kuik, O., \& Tol, R. S. J. (2017). Economic growth and carbon dioxide emissions : An analysis of Latin America and the Caribbean. Atmósfera, 30(2), 87-100. https://doi.org/10.20937/ATM.2017.30.02.02

Kahn, M. E., Mohaddes, K., Ng, R. N. C., Pesaran, M. H., Raissi, M., \& Yang, J. (2019). Long-Term Macroeconomic Effects of Climate Change: A Cross-Country Analysis. Globalization Institute Working Paper.

Kasperowicz, R. (2015). Economic growth and CO2 emissions: the ECM analysis. Journal of International Studies, 8(3), 91-98. https://doi.org/10.14254/2071-8330.2015/8-3/7

Li, P., \& Ouyang, Y. (2019). The dynamic impacts of financial development and human capital on co2 emission intensity in china: An ardl approach. Journal of Business Economics and Management, 20(5), 939-957. https://doi.org/10.3846/jbem.2019.10509

Marques, A.C., Fuinhas, J.A. \& Menegaki, A. . (2016). Renewable vs non-renewable electricity and the industrial production nexus: Evidence from an ARDL bounds test approach for Greece. Renewable Energy, 96, 645- 
655.

McSweeney C, Lizcano G, New M, and Lu X. (2010). The UNDP Climate Change Country Profiles. Bulletin of the American Meteorological Society 91, 157-66

Mehrara, M., \& Musai, M. (2013). The Relationship between Economic Growth and Human Capital in Developing Countries. International Letters of Social and Humanistic Sciences, 5, 55-62. https://doi.org/10.18052/www.scipress.com/ilshs.5.55

Melissa Dell, Benjamin F.Jones, \& Benjamin A., O. (2008). CLIMATE CHANGE AND ECONOMIC GROWTH : NATIONAL BUREAU OF ECONOMIC RESEARCH.

Mikayilov, J. I., Galeotti, M., \& Hasanov, F. J. (2018). The Impact of Economic Growth on CO2 Emissions in Azerbaijan. WORKING PAPER SERIES ISSN 1973-0381. https://doi.org/10.1016/j.jclepro.2018.06.269

Mitaj, A., Muco, K., \& Avdulaj, J. (2016). The Role of Human Capital in the Economic Development and Social Welfare In Albania. International Journal of Human Resource Studies, 6(1), 63. https://doi.org/10.5296/ijhrs.v6i1.9059

Muttarak, R., \& Lutz, W. (2014). Is education a key to reducing vulnerability to natural disasters and hence unavoidable climate change? Ecology and Society, 19(1). https://doi.org/10.5751/ES-06476-190142

Nuryartono, N., \& Rifai, M. A. (2017). Analysis of Causality between Economic Growth , Energy Consumption and Carbon Dioxide Emissions in 4 ASEAN Countries. 7(6), 141-152.

Nyasha, S., Gwenhure, Y., \& Odhiambo, N. M. (2018). Energy consumption and economic growth in Ethiopia: A dynamic causal linkage. https://doi.org/10.1177/0958305X18779574

Obialor, M. C. (2017). Effect of Government Human Capital Investment on Economic Growth in Sub-Saharan Africa: Evidence from Nigeria, South Africa and Ghana (1980-2013). International Journal of Asian Social Science, 7(4), 328-339. https://doi.org/10.18488/journal.1/2017.7.4/1.4.328.339

Pesaran, M. and Shin, Y. (1999). An Autoregressive Distributed Lag Modeling Approach to Cointegration Analysis” in S. Strom, (ed) Econometrics and Economic Theory in the 20th Century: The Ragnar Frisch centennial Symposium, Cambridge University Press, Cambridge.

Pesaran, M.H., Shin, Y. and Smith, R. . (2001). Bounds testing approaches to the analysis of level relationship. Journal of Applied Economics, 16, 289-326. https://doi.org/10.3390/economies6010002

Phillips Peter C. B and Pierre, P. (1988). Testing for a unit root in time series regression. Biometrika, 75(2), 335346.

Perman, Yue M., J. M. and M. C. (2003). Natural Resouces and Environmental Economics. 3rd ed. Harlow, UK: Pearson Education. In Marine Resource Economics. https://doi.org/10.1086/mre.7.4.42629040

Robinson, S., Strzepek, K., \& Cervigni, R. (2013). The Cost of Adapting to Climate Change in Ethiopia : SectorWise and Macro-Economic Estimates. Ethiopia Strategy Support Program II (ESSP) Working Paper 53, (EDRI and IFRI. Addis Ababa).

Roos, M. W. M. (2017). Endogenous Economic Growth, Climate Change and Societal Values : A Conceptual Model. https://doi.org/10.1007/s10614-017-9707-3

Ru, M., Shindell, D. T., Seltzer, K. M., Tao, S., \& Zhong, Q. (2018). The long-term relationship between emissions and economic growth for $\mathrm{SO} 2, \mathrm{CO} 2$, and $\mathrm{BC}$. Environmental Research Letters Https://Doi.Org/10.1088/1748-9326/Aaece2.

Saidi, K., \& Hammami, S. (2015). The impact of CO2 emissions and economic growth on energy consumption in 58 countries. Energy Reports, 1, 62-70. https://doi.org/10.1016/j.egyr.2015.01.003

Salisu, A., \& Bubari, H. U. (2019). Dynamics of Human Capital and Economic Growth in West African Countries : A Panel Data Approach.

Samuel, F., \& Nicholas, S. (2016). Climate Change, Development, Poverty and Economics. Grantham Research Institute on Climate Change and the Einvironment.

Smith, A. (1904). An Inquiry in the Nature and Causes of the Wealth of Nations, London, Meuthen and Co, Ltd. American Journal of Sociology. https://doi.org/10.1086/217862

Stern, N. (2008). The Economics of Climate Change The Economics of Climate Change. American Economic Review:, 98(2), 1-37.

Striessnig, E., Lutz, W., \& Patt, A. G. (2013). Effects of Educational Attainment on Climate Risk Vulnerability. $18(1)$

UN, 1992, United Nations Framework Convention on Climate Change, http://unfccc.int/resource/docs/convkp/conveng

UN. (1990). United Nations Development Programme;Concept and Measurement of Human Development: Human Development Report.

UN. (2018). United Nations Development Programme; Human Development Report; Human Development Indices and Indicators.

UN. (2019). United Nations Development Programme; Department of Economic and Social Affairs, Population Division (2019). World Population Prospects 2019, Volume I: Comprehensive Tables (ST/ESA/SER.A/426). 
UNESCO. (2011). 'Climate Change Education for Sustainable Development in Small Island Developing States'. UNESCO Experts Meeting 21-23 September 2011, Nassau: Commonwealth of the Bahamas. (September).

Wang, Z., Hao, P., \& Yao, P. (2017). Non-Linear Relationship between Economic Growth and CO 2 Emissions in China: An Empirical Study Based on Panel Smooth Transition Regression Models. 1-11. https://doi.org/10.3390/ijerph14121568

World Bank. (2010). Development and Climate Change; World deveolpment report. https://doi.org/10.3334/CDIAC/cli.002

World Bank (2018), Human Capital Project, The World Bank Group, 1818 H Street NW, Washington, DC 20433, USA 